\title{
Entrepreneurship as a dynamic field of study: a bibliometric analysis of research output
}

\author{
El emprendimiento como campo dinámico de studio: un análisis bibliométrico de rendimiento
}

\author{
Luis Javier Cabeza Ramírez \\ University of Cordoba, Faculty of Law and Business and Economic Sciences, \\ Puerta Nueva s/n, 14071 Córdoba, España, r62caral@uco.es \\ Sandra Mạ Sánchez Cañizares \\ University of Cordoba, Faculty of Law and Business and Economic Sciences, \\ Puerta Nueva s/n, 14071 Córdoba, España, sandra.sanchez@uco.es \\ Fernando J. Fuentes García \\ University of Cordoba, Faculty of Law and Business and Economic Sciences, \\ Puerta Nueva s/n, 14071 Córdoba, España, fernando.fuentes@uco.es
}

\begin{abstract}
The present study's objective was to carry out a systematic literature review whose main value lies in updating and analysing the current state of scientific production in the field of entrepreneurship based on the best known international bibliographic databases, Web of Science and Scopus. To this end, the relevant papers published in indexed international journals were selected from both databases. The most-cited research was identified by setting a standardised threshold number of citations based on the $\mathrm{H}$ index called ' $\mathrm{H}$-Classics', which is sensitive to the particular characteristics of each research area. This study analysed the most important authors, years of greater production, journals, cited authors, themes, subject areas, text typology, countries, institutional affiliations and keywords. The results are rankings of journals and authors based on the weights given by both databases' $\mathrm{H}$-index for citation frequency.
\end{abstract}

Keywords: Literature review, $\mathrm{H}$-index, entrepreneurship.
Resumen

El objetivo del presente trabajo de investigación es realizar una revisión sistemática de la literatura (RSL) cuya principal utilidad sea la de actualizar y analizar el estado de la producción científica en el campo del entrepreneurship según las dos bases de datos bibliográficas más reconocidas a nivel internacional: Web o Science (WOS) y Scopus. Para ello se han recuperado una selección de documentos publicados en las revistas internacionales indexadas en ambas bases de datos. La selección de documentos más citados se realizó fijando un umbral de citación estandarizado basado en el índice $\mathrm{H}$ denominado $\mathrm{H}$-Classics sensible a las características propias de cualquier disciplina de investigación. Se analizan los autores más relevantes, años de mayor producción, revistas, autores referenciados, temas, áreas de conocimiento, tipología documental, países, afiliaciones y palabras clave. Los resultados aportan un ranking de revistas y autores aplicando una ponderación del $\mathrm{H}$-Index por su frecuencia respectiva en cada base de datos.

Palabras clave: Revisión de la literatura, índice H, entrepreneurship.

\section{Introduction}

Attempting a characterisation of entrepreneurs or entrepreneurship, in general, has become an enormous task due to the increase of entrepreneurship studies in recent years. The formation of new companies plays a vital role in economic growth and development in many countries, as entrepreneurial activities are linked to job creation, generation of wealth, increased competitiveness and technological development.

Since 1985, the number of conferences, seminars, study programmes, professorships, books, reviews and papers has grown continuously. As a result, this field is currently going through one of its best periods. Access to, and the growth of, electronic databases (e.g. World of Science [WoS], Scopus and Google Scholar) offers the scientific community immediate, easy and almost unlimited access to the knowledge available on this subject area at any given moment. A basic search in January 2016 with the word 'entrepreneur' in the above-mentioned databases produced the following results: 21,149 entries for WoS, 21,162 for Scopus and, for Google Scholar, approximately 625,000 entries.

Gradually, a universe of literature has been generated that has become increasingly unmanageable for entrepreneurship studies, intensifying the difficulty of interpreting, analysing and understanding relevant findings and distinguishing them from other non-essential results. This excess of information has become so overwhelming that it hinders an understanding of a field plagued by disparities and contradictions about what is or is not entrepreneurship (Audretsch, Kuratko \& Link, 2015).

One often gets the impression that each new study, paper, review and dissertation about entrepreneurship, time and again, refers to the field's origins without knowing clearly what this was or should be. This literary deja vu periodically reopens the same debates that have continued to drag on in the absence of agreement in the scientific community. What is the definition of entrepreneur? Is there a single theory that explains entrepreneurship? What constitutes entrepreneurship research? These reiterative questions constitute the main barrier to an accurate approximation of entrepreneurship. However, both this concept and the area of research itself may possibly have remained so undefined that the central question may now be how this field can succeed when the literature about this topic is so extensive.

In this context, an updated systematic literature review (SLR) is clearly needed, based on a bibliometric analysis of research output. Such a review would contribute not only to the field's 
legitimisation but also to settling the debate this subject area has generated (Veciana, 2006). Because this debate is reopened every few years, it weakens the rigour and relevance of the field's findings (Frank \& Landström, 2015).

This review combines a wider selection of texts (i.e. articles, books, chapters, reviews and conference presentations) than previous studies with a similar goal. The present review's main novelty lies in integrating the most important scientific databases (i.e. WoS and Scopus) into the selection of articles studied.

Therefore, this study's main objective is to get to the heart of the literature on entrepreneurship through its most important authors, publication years, journals, citations, themes, subject areas, text typology, countries, institutional affiliations and keywords. While this paper has its limitations, as do all reviews (Hunter \& Schimdt, 2014), it contributes to resolving the difficulties implicit in reviewing a large volume of literature (Moroz \& Hindle, 2012). To this end, this review used software created specifically to facilitate the management of large quantities of information based on text mining, classification systems and text filtering. The final results reveal the primary texts that contain the axioms and proposals that have since been widely accepted by the scientific community.

\section{Literature review}

From its early authors, which include, among others, Richard Cantillon (1680-1734), Anne-Robert Jacques Turgot (1727-1781), Jena-Baptiste Say (1767-1832), John Stuart Mill (1806-1973), Carl Menger (1840-1921), Joseph Schumpeter (1883-1950) and Ludwing von Mises (1881-1973), until the present moment, the concept of entrepreneurs and the subject area itself have been addressed by an ever greater number of researchers (Minniti,
2013). This intensified, from the very beginning, into the first great crisis of the twenty-first century.

The controversy over the legitimacy of entrepreneurship as a field of research separate from others such as management resulted in some authors even rejecting entrepreneurship as lacking a consolidated theoretical framework (Genesca \& Aponte, 2003) or, at least, as not sufficiently distinct from other fields. This question has been discussed since the beginning by some of the most important authors, such as Low and MacMillan (1988), Shane and Venkataraman (2000) and Stevenson and Jarillo (1990), who highlighted the multidimensional, transversal and complex nature (Boulard, 2011) of a phenomenon analysed within such disparate areas of expertise as anthropology, economics, finances, history, psychology, political science, sociology and others.

In the 80 s and beginning of the 90s - and coinciding with the exponential growth of the number of publications about entrepreneurship - this debate reached its greatest intensity, pressing home the need for all sides to agree on a common framework (Amit, Glosten \& Muller, 1993; Gartner, 1985; Vesper, 1983). Some groups, in opposition to this, insist that the absence of this common ground guarantees future progress (Bygrave \& Hofer, 1991). The conflict finally caused Low (2001) to warn researchers that entrepreneurship could eventually fuse into a secondary field made up of a disjointed mishmash of knowledge.

Far from fulfilling this dire prediction, the field's growth has been unstoppable, with specialised publications, conferences, professorships, journal articles and research programmes (Díaz, 2002) providing strong evidence of this. A quick look at the most important databases (i.e. Scopus and WoS) that gather together scientific output also evinces this. The number of publication has continued to grow, especially after 1985 (see Figure 1).

Figure 1. Number of documents by year (Scopus/WOS)

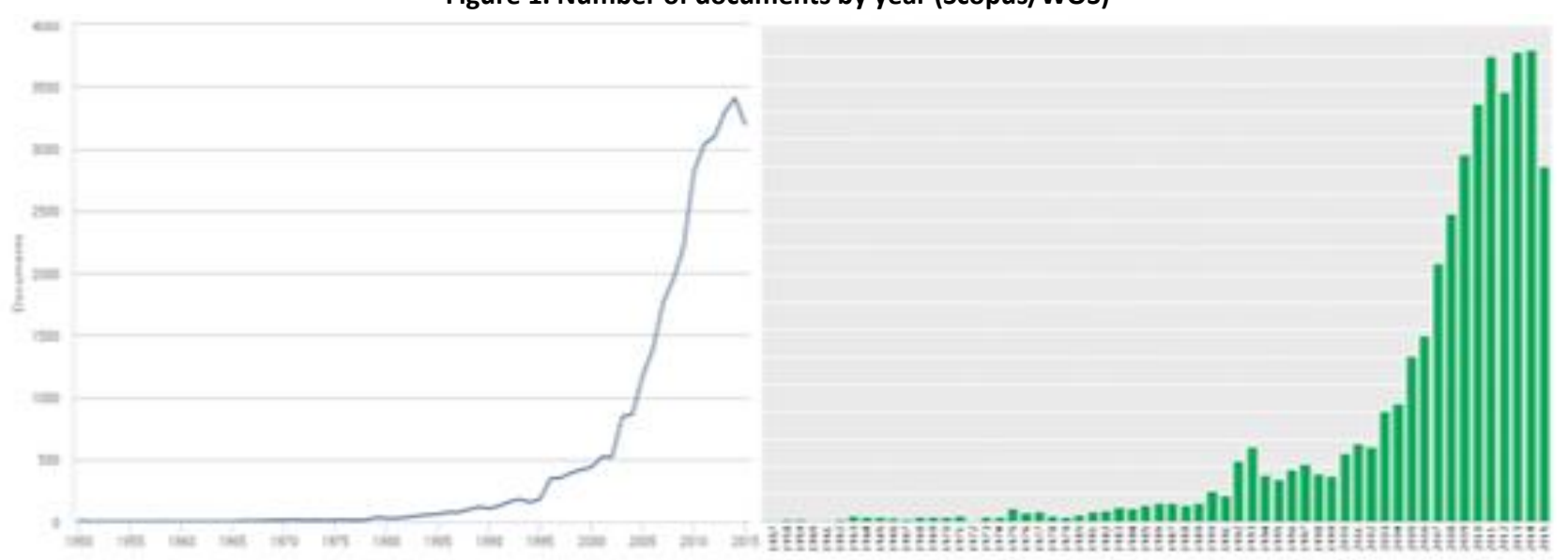

Source: Own source from Scopus and WOS.

Often one of any researcher's first tasks is to align his or her work by doing a traditional literature review as a way to understand in depth the relevant field's past evolution and the main definitions and theories that directly affect the researcher's work. A brief overview along these lines was offered in the above discussion that presents a subjective perception of the field's problems, which ignores the importance of literature reviews in understanding entrepreneurship as a full-fledged subject area - if the reviews are more objective and less narrowly targeted.
Even without reference to experts' frequent assessment of SLRs' contributions, the exponential growth of papers has meant that, in recent years, the number of this type of review has increased as an appropriate method, since these are notable for the transparency and repeatability of their processes (Tranfield \& Smart, 2003). SLRs use methodologies proposed by, among others, Beltrán (2005), Khalid and Kunz (2003), Kitchenham (2004), Petticrew and Roberts (2006) and Tranfield and Smart (2003). While this method originated in human sciences and medical bibliographic reviews, it has been shown to be perfectly adaptable 
for the social sciences (Petticrew \& Roberts, 2006), having been employed in multiple studies related to the field of entrepreneurship, including Denyer and Neely (2004), Jones, Coviello \& Tang (2011), Liñán and Fayolle (2015), Pittaway, Robertson, Munir, Denyer \& Neely (2004), Pittaway, Holt \& Broad (2014) and Thorpe, Holt, Macpherson, \& Pittaway (2005).

One of the most complete SLRs, without doubt, was done by Landstöm (2012), in which the cited author used bibliometric tools to compile the 'basic knowledge' of texts from 1980 to 2006. To this example, others can be added that make clear how this kind of analysis strengthens the legitimacy of entrepreneurship. Cuervo, Ribeiro \& Roig (2006) selected articles based on impact factors in EBSCO and the Institute for Scientific Information's (ISI) Journal Citation Reports (JCR). Teixeira and Ferreira (2013) examined the field of entrepreneurship research and its scientific structure by means of the relationships established between the most influential authors, exploring so-called 'invisible schools' based on three journals: Entrepreneurship Theory and Practice, Journal of Business Venturing and Small Business Economics. Karatas-Ozkan and Chell (2013) put forward the principles of how to implement SLR in entrepreneurship research as an integrative and reflexive method, describing its basic features and limitations. Wang and Jessup (2014) evaluate and summarise previous research in the field, focusing on dependent variables that affect entrepreneurial activities in Europe and the U.S., from 2002 to 2012. Liñán and Fayolle (2015) focus on the subtopic of entrepreneurial intentions, from 2004 to 2013, looking specifically at citation and thematic analysis.

\section{Methodology}

In order to carry out an analysis of entrepreneurial research output, which is this study's objective, the methodology proposed by Tranfield \& Smart (2003) was applied. This approach can be separated into three phases, as shown below in Figure 2 .

Figure 2. Phases of the systematic literature review

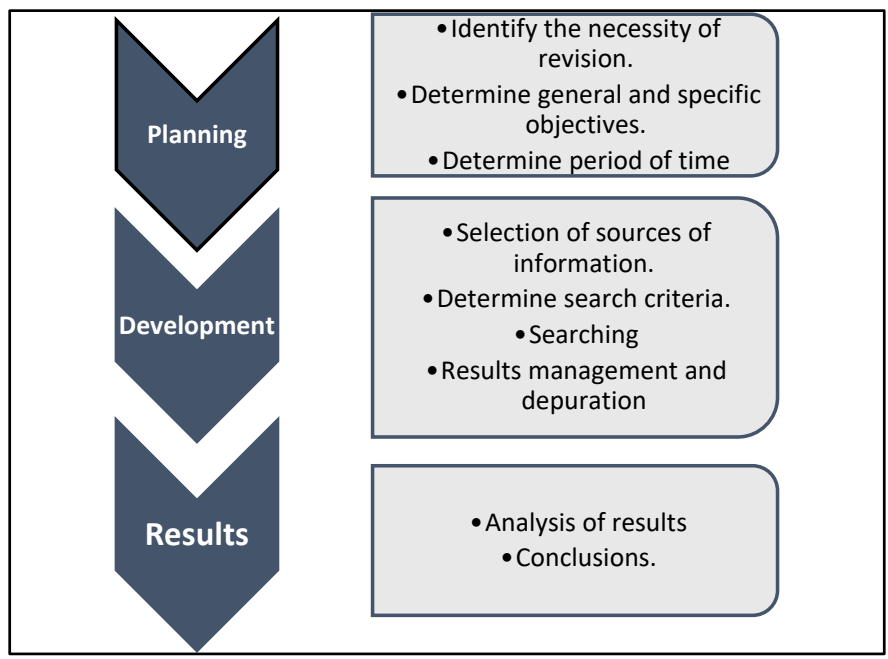

Source: adapted from Tranfield \& Smart (2003).

The planning phase started with identifying the need for this review, as well as establishing the objectives to be met, as discussed in the above introduction. Next, the time needed to understand the greatest number of years possible was defined, since this, in turn, would increase the results' representativeness, given a target population of so many texts. The range of time/papers to be processed needed to date back to the first indexed and/or cited texts in both databases and extend up to the time of the present study's first information searches and downloads (i.e. January 2016). Obviously, this review needs to leave the door open for future updates, since entrepreneurship research is a dynamic field that is always expanding.

In terms of carrying out the research, as discussed above, this review sought to capture the primary essence of the field. Therefore, secondary sources of information used were not limited to journal articles but also included books, conference proceedings, reviews and conference papers. According to Cuervo, Ribeiro \& Roig (2006), when citations in articles are being studied, these are also to be found incorporated in books and articles not indexed in databases (i.e. WoS and Scopus). Thus, in the present study, it did not make sense to exclude these sources a priori. Furthermore, since the databases were combined, when duplicate entries appeared, the relevant sources were eliminated when the resulting data files were standardised.

The present study differed from previous research in that this review mainly looked at journal articles, which made up the majority of texts reviewed. In addition, other sources of information available in WoS and Scopus were included in order to enrich the results and verify if different types of texts can be dispensed with when carrying out a comprehensive $\mathrm{SLR} /$ bibliometric analysis - without affecting the results.

The next phase in the review process involved justifying the selection of databases searched (i.e. WoS and Scopus), whose most characteristic traits are given below:

1) WoS: This is considered the standard database for analyses of scientific fields, in part because of the citation indexes produced by the ISI, which were created by E. Garfield in 
1960. The WoS provides citation indexes in the sciences (i.e. Science Citation Index), social sciences (i.e. Social Science Citation Index) and arts and humanities (i.e. Art \& Humanities Citation Index). This database provides access to chemistry data (i.e. Current Chemical Reactions and Index Chemicus) and to conferences (i.e. Conference Proceedings Citation Index in Science and Conference Proceedings Citation Index in Social Science \& Humanities). WoS indexes a large quantity of journals on the abovementioned topics, updating this on a weekly basis and thus maintaining the largest long-term archive of bibliographic information on scientific production in journals.

2) Scopus: This database is updated daily with abstracts and citations of publications in journals and conferences on different scientific areas (i.e. health sciences, social sciences and arts and humanities), including approximately 18,000 titles from 5,000 publishers. Scopus has its own online platform that provides indicators of the quality and impact of publications and journals, with a ranking of journals and countries that facilitate analyses of scientific domains (i.e. SClmago Journal \& Country Rank). This database has its own indicator of impact that offers an alternative to the JCR - the SCImago Journal Rank - which is based on the relevance algorithm used by Google (i.e. PageRank).
Despite analyses of the advantages and disadvantages of using WoS over Scopus, and vice versa, such as linguistic or geographical bias in WoS in favour of U.S./British English language journals (Mártinez Sánchez, 2014) or the larger textual universe of Scopus compared to WoS (Falagas, Pitsouni, Malietzis, \& Pappas 2008), various comparative studies (Meho \& Yang, 2007; Norris \& Oppenhein, 2007) have not found a clear winner. This indicates that a combination of the two is the best solution for comprehensive bibliometric studies like the present one.

Next, the processing software needed to be selected that would expand the analysis to all types of texts, without time restrictions and for the above-mentioned databases. The present study used the free online software tool STICCI.eu (i.e. Software Tool for Improving and Converting Citation Indices - enhancing uniformity), created by Gómez Jauregui, Gomez-Jauregui, Manchado \& Otero (2014) and applied by Del Val (2015). Based on the Smith-Waterman algorithm, this software standardises, and corrects errors in, citations contained in different electronic databases (Libman, 2007; Vieira \& Gomes, 2009), and it also is able to convert citations into different file formats (i.e. WoS, Scopus, CSV, BibTeX and RIS). In the search criteria, given the equivalency of subject areas in WoS and Scopus, the syntax and references filters were formulated according to the subject areas defined in both databases (see Table 1).

Table 1. Number of documents filtered by subject areas

\begin{tabular}{|c|c|c|}
\hline & wos & Scopus \\
\hline Date & \multicolumn{2}{|c|}{$30 / 01 / 2016$} \\
\hline Source & Web of Science Core Collection & Social Siences and Humanities \\
\hline Type & Simple & Simple \\
\hline Number of documents & 32486 & 36264 \\
\hline Sintax & entrep*/topic & entrep*/Article title, abstract, keywords \\
\hline Filtered by areas & $\begin{array}{l}\text { (management or business or economics or } \\
\text { planning development or history or social } \\
\text { issues or education educational research or } \\
\text { operations research management science or } \\
\text { business finance or environmental studies } \\
\text { or sociology or geography or political } \\
\text { science or social sciences interdisciplinary or } \\
\text { engineering industrial or history of social } \\
\text { sciences or area studies or urban studies or } \\
\text { public administration or computer science } \\
\text { information systems or information science } \\
\text { library science or psychology applied or } \\
\text { international relations or multidisciplinary } \\
\text { sciences or anthropology or psychology } \\
\text { multidisciplinary or law ) }\end{array}$ & $\begin{array}{l}\text { SUBJAREA (mult OR arts OR busi OR deci OR } \\
\text { econ OR psyc OR soci) AND (LIMIT-TO ( } \\
\text { SUBJAREA, "BUSI") OR LIMIT.TO (SUBJAREA, } \\
\text { "SOCI") OR LIMIT-TO (SUBJAREA, "ECON") } \\
\text { OR LIMIT-TO (SUBJAREA, "ENGI") OR LIMIT- } \\
\text { TO (SUBJAREA, "DECI") OR LIMIT-TO } \\
\text { (SUBJAREA, "ENVI") OR LIMIT-TO (SUBJAREA, } \\
\text { "PSYC") OR LIMIT-TO (SUBJAREA, "COMP") } \\
\text { OR LIMIT-TO (SUBJAREA, "MULT") }\end{array}$ \\
\hline Number of documents & 27279 & 35517 \\
\hline
\end{tabular}

Source: Authors (based on WoS and Scopus).

Once the textual universe of 62,796 references was obtained, it was necessary to determine the citation threshold that the texts had to reach to be included in the present analyses, namely, from which number of citations or higher can a text be considered 'classic literature' or a 'citation classic' (Garfield, 1977). The concept of H-Classics, developed by Martínez Sánchez (2014), was applied. The calculations were based on the $\mathrm{H}$-Index for the field of research in question. The application of this index to entrepreneurship was not without its challenges: a) The H-Index had to be determined for a field of research fragmented into different subareas.

b) The H-Index had to be applied to two databases, which, as can be seen in Table 1 above, do not have identical classification systems

c) Scopus does not include complete reference information for articles published before 1996.

However, the above-mentioned citation threshold could be determined as a result of the equivalency between subject areas in both databases: 
a) The H-Index was calculated from WoS's subcategories that cover entrepreneurship, ordering the articles by number of times they were cited, from most to least, going through the list until the last publication was found with the corresponding number of citations less than or equal to the citation threshold.

b) The H-Index was obtained for the Scopus categories by following the same procedure.

In WoS, the total number of texts that contain the root 'entrep*', in all the categories, is 44,943 , although some of the texts fell into more than one category, for example, 'management' and 'business'. These duplicates were removed, so the above number was reduced to 32,486 . After the texts were filtered, the number was 27,279 , a process that produced similar results in Scopus. The citation threshold for $\mathrm{H}$-Classics in the entire field in WoS was set at 196. In other words, in WoS, the first 196 entries, in order from greatest to least citation frequency, were selected. The same procedure in Scopus resulted in 221 texts.

With the selection criteria established, the automatic searches that fulfilled the imposed conditions were carried out, and the results were exported to a citation manager programme (i.e. Endnote X6.0.1), and then to Excel and Access for subsequent treatment. In this way, greater flexibility was achieved in all subsequent processing of citations (Marín-García, 2008). While the automatic search guarantees that the database generated satisfies pre-established conditions, it is useful to confirm the results - text by text - to verify, refine and detect any texts that do not fit in with the study's objectives. It is important to point out that, if researchers deal with different sources of data that are not homogeneous or standardised, these need to be complementary. Obviously, texts exist that overlap between databases, that is, that are found in both (i.e. Scopus and WoS), and that must be eliminated, leaving those entries that index more information to be analysed. In the present case, it was the texts from WoS that prevailed, since Scopus did not have complete information on citations for articles published before 1996.

By truncating the prefix 'entrep"' - with various possible spellings and endings - the final number of texts to be included in the present study was obtained: 196 from WoS and 221 from Scopus, for a total of 417 . Of these, 136 appeared in both databases and were eliminated before treatment, with preference given to those contained in WoS for the above-mentioned reason, with a final result of 281 texts (i.e. 196 from WoS and 85 from Scopus).
With the set of relevant texts delimited, the analysis next involved putting the data through a tedious and lengthy process of management, refinement and standardisation. Applying the $\mathrm{H}$ Classics methodology and the indexes associated with entrepreneurship, the final analysis began with the 281 cases of classic literature or citation classics, which were both the reference point and point of departure of the present research. The list of these 281 references is available unpon request. The main findings are described in the following section.

\section{Results}

The main results in question focus on analyses of years, authors, journals, type of text, countries and language of publication, authors' institutional affiliations and author and $\mathrm{H}$-Classics index keywords. These findings offer an ample enough panorama to reveal the particularities of the most relevant texts in the field of entrepreneurship, throughout the entire period selected in the databases in question.

\subsection{Years}

After discrepancies and inconsistencies found involving 'impossible' years, such as ' 4,856 ', the articles were checked and errors eliminated by thoroughly checking the records. The resulting data were analysed to determine the years most often cited by H-Classics, as well as citation frequency. Only three studies are cited that were published before the $80 \mathrm{~s}$. After that date, the number of texts that come in over the limit set for the $\mathrm{H}$-Classics index progressively increases, reaching the highest number from 1995 to 2006 , during which $70 \%$ of the citation classics appear. Logically, given that articles' exposure to the possibility of being cited grows with each year that passes, the older the article is, the more likely it is to appear among those most cited, thereby becoming a reference point.

This kind of study cannot be static since reviews need to be updated from time to time because new trends can arise that revive interest in certain texts, which then become authentic future reference points. For example, a more exhaustive analysis could be carried out of the evolution of citation classics from 2007 onwards, the point at which the global economic crisis began and many eyes turned to entrepreneurship as a way to soften the crisis's devastating consequences. Figure 3 shows the distribution over time of the 281 citation classics selected.

Figure 3. H-Classics over time

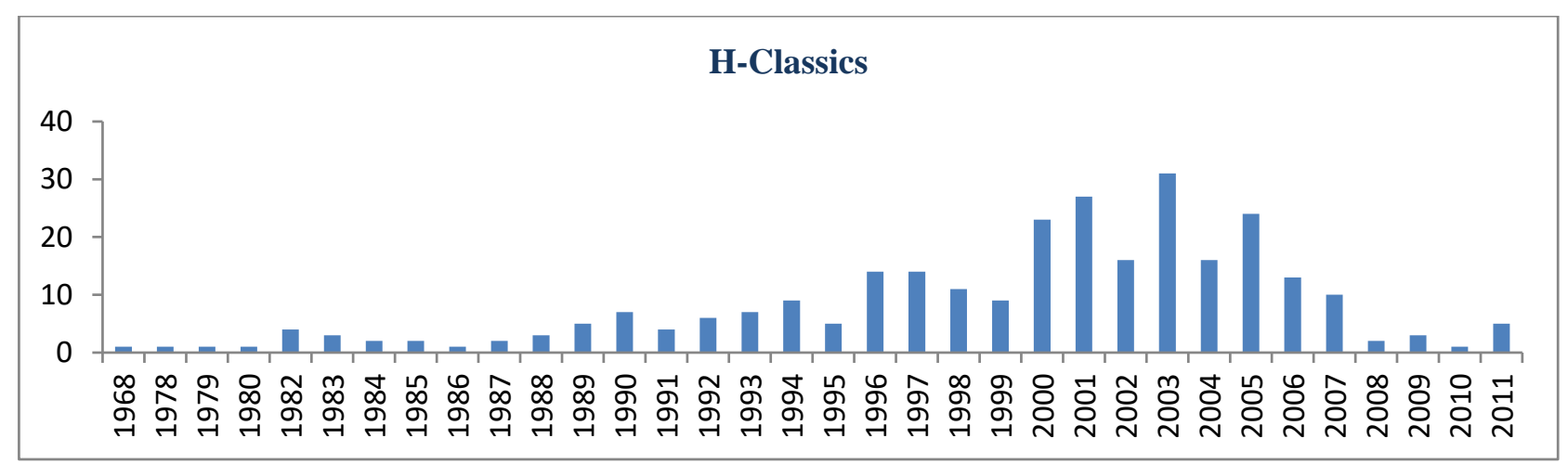

Source: Authors. 
Similarly, the texts cited by the classic literature were analysed, as the cited texts are a veritable fount of knowledge about entrepreneurship. These also can be found within a quite specific period - between 1990 and 2000 - when $50 \%$ of the cited texts were published (see Figure 4).

Figure 4. Cited by H-Classics over time

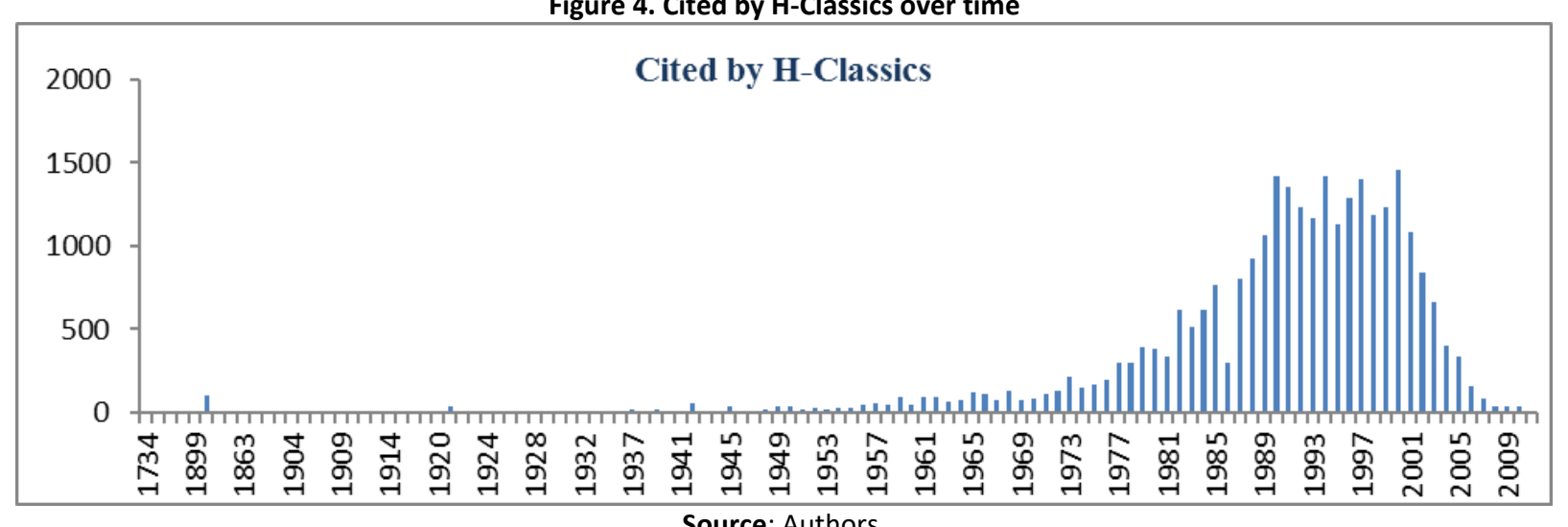

Source: Authors.

\subsection{Authors}

In the 281 texts identified - including texts with two or three authors - a total of 455 authors are termed 'H-Classics authors', among whom stand out S. A. Zahra, S. A. Shane, H. E. Aldrich, P. P. McDougall, V. Nee, B. M. Oviatt and H. J. Sapienza as the most prolific, with five or more texts being most cited. These classic authors, in turn, cite others who together constitute the emergence of entrepreneurship as a field, among whom are the most influential scholars who appear the most often, that is, they are cited repeatedly in the classic literature. They thus have become the genuine 'gene' for entrepreneurship research. Of the 20,171 authors identified, the following stand out: H. E. Aldrich, S. A. Zahra, D. Miller, J. A. Schumpeter and S. A. Shane - to mention just those who are cited over 100 times. Without delving too deeply into this aspect, it is possible to observe that certain classic authors have, in their turn, been seminal to this field of study (see Table 2).

Table 2. Main H-Classics authors and Cited by H-Classics authors

\begin{tabular}{|c|c|c|c|}
\hline H-Classics Authors & Frequency & Cited by H-Classics & Frequency \\
\hline Zahra S.A. & 11 & Aldrich H. E. & 147 \\
\hline Shane S. A. & 8 & Zahra S.A. & 133 \\
\hline Aldrich H. E. & 5 & Miller D. & 122 \\
\hline McDougall P. P. & 5 & Schumpeter J. A. & 112 \\
\hline NEE V & 5 & Shane S. A. & 108 \\
\hline Oviatt BM & 5 & Covin J.G. & 90 \\
\hline Sapienza HJ & 5 & Kirzner I. M. & 90 \\
\hline Autio $\mathrm{E}$ & 4 & Barney J.B. & 83 \\
\hline Baron RA & 4 & Porter M.E. & 81 \\
\hline Busenitz LW & 4 & Cooper A.C. & 78 \\
\hline Davidsson P & 4 & Reynolds P. D. & 77 \\
\hline Dess GG & 4 & Gartner W.B. & 76 \\
\hline FRESE M & 4 & Hitt M. A. & 68 \\
\hline Gartner W.B. & 4 & Teece D. J. & 67 \\
\hline Ireland RD & 4 & March J.G. & 66 \\
\hline Lumpkin GT & 4 & Eisenhardt K.M. & 63 \\
\hline Shepherd D & 4 & Audretsch D.B. & 60 \\
\hline Coviello NE & 3 & Dimaggio P. J. & 60 \\
\hline Covin J.G. & 3 & Williamson O. E. & 60 \\
\hline Etzkowitz H & 3 & Burt R. S. & 55 \\
\hline Hitt M. A. & 3 & Hannan M. T. & 55 \\
\hline Knight G. A. & 3 & Burgelman R. A. & 52 \\
\hline Kogut B & 3 & Granovetter M. S. & 52 \\
\hline Locke E. & 3 & McDougall P. P. & 51 \\
\hline Miller D. & 3 & Nelson R. R. & 51 \\
\hline Peng MW & 3 & Weick K. E. & 51 \\
\hline Portes A & 3 & Evans D. S. & 50 \\
\hline Stuart T & 3 & MacMillan I. C. & 50 \\
\hline WOO CY & 3 & Mintzberg H. & 49 \\
\hline
\end{tabular}


To select the most classic studies of these researchers, the present study used the H-Classics index, which is based on the Hirsch index (i.e. H-index). By applying this index to the cited authors' work, the most outstanding studies within the same field of study can be detected, based on the assumption that all authors are a part of a common area (i.e. entrepreneurship). This offers a measure of the quality and impact of any authors' scientific output. Within the multiple variations, advantages and disadvantages of this index (Bornmann \& Marx, 2011; Schreiber, 2010), this study opted for adapting the index for $\mathrm{H}$-Classics and another for works cited by $\mathrm{H}$ Classics. In this way, the first version of results shows the frequency or number of articles found among those most cited with the H-Index, both of WoS and Scopus, and the second version indicates the number of times articles appear in $\mathrm{H}$-Classics, also with the $\mathrm{H}$-Index of both databases.

With the objective of uniting the two databases into one single index, an $\mathrm{H}$-frequency (HF) coefficient was developed, which was calculated with the weighted average between the frequencies of each database with respect to its corresponding $\mathrm{H}$-Index. To do this, the following formula was applied:

$$
H F=\frac{\text { WoS Frequency } * \text { WoS H.Index }+ \text { Scopus Frequency } * \text { Scopus H.Index }}{\text { WoS H.Index }+ \text { Scopus H.Index }}
$$

With this weighted index, a ranking of authors could be produced that takes into account not only the number of texts (i.e. frequency) in the databases but also the respective $\mathrm{H}$-Index for both. Table 3 highlights in colour the first 10 authors of this ranking, at the time the present study was done (i.e. January 2016). At that moment in time, Zahra appears as the most important researcher in this field, followed by Shephard - with Shane in third place.

Table 3. FH for main H-Classics authors

\begin{tabular}{|c|c|c|c|c|c|c|}
\hline H-CLASSICS & $\begin{array}{c}\text { H-Index } \\
\text { WOS }\end{array}$ & $\begin{array}{l}\text { H-Index } \\
\text { SCOPUS }\end{array}$ & $\begin{array}{l}\text { Frec. } \\
\text { Total }\end{array}$ & $\begin{array}{l}\text { Frec } \\
\text { WOS }\end{array}$ & $\begin{array}{c}\text { Frec. } \\
\text { Scopus }\end{array}$ & FH \\
\hline Zahra S.A. & 48 & 48 & 11 & 6 & 5 & 5,5 \\
\hline Shane S. A. & 21 & 44 & 8 & 7 & 1 & 2,9 \\
\hline Aldrich H. E. & 29 & 22 & 5 & 5 & 0 & 2,8 \\
\hline McDougall P. P. & 24 & 23 & 5 & 4 & 1 & 2,5 \\
\hline Nee V & 22 & 18 & 5 & 3 & 2 & 2,6 \\
\hline Oviatt BM & 15 & 13 & 5 & 4 & 1 & 2,6 \\
\hline Sapienza HJ & 25 & 26 & 5 & 3 & 2 & 2,5 \\
\hline Autio $\mathrm{E}$ & 19 & 21 & 4 & 3 & 1 & 2,0 \\
\hline Baron RA & 46 & 39 & 4 & 2 & 2 & 2,0 \\
\hline Busenitz LW & 19 & 20 & 4 & 4 & 0 & 1,9 \\
\hline Davidsson $\mathrm{P}$ & 20 & 27 & 4 & 3 & 1 & 1,9 \\
\hline Dess GG & 25 & 20 & 4 & 3 & 1 & 2,1 \\
\hline Frese M & 41 & 43 & 4 & 4 & 0 & 2,0 \\
\hline Gartner W.B. & 24 & 23 & 4 & 2 & 2 & 2,0 \\
\hline Ireland RD & 37 & 31 & 4 & 3 & 1 & 2,1 \\
\hline Lumpkin GT & 22 & 22 & 4 & 4 & 0 & 2,0 \\
\hline Shepherd D & 36 & 1 & 4 & 4 & 0 & 3,9 \\
\hline Coviello NE & 14 & 19 & 3 & 1 & 2 & 1,6 \\
\hline Covin J.G. & 30 & 26 & 3 & 2 & 1 & 1,5 \\
\hline Etzkowitz H & 17 & 24 & 3 & 3 & 0 & 1,2 \\
\hline Hitt M. A. & 60 & 54 & 3 & 3 & 0 & 1,6 \\
\hline Knight G. A. & 10 & 19 & 3 & 3 & 0 & 1,0 \\
\hline Kogut B & 31 & 26 & 3 & 1 & 2 & 1,5 \\
\hline Locke E. & 59 & 49 & 3 & 2 & 1 & 1,5 \\
\hline Miller D. & 50 & 37 & 3 & 2 & 1 & 1,6 \\
\hline Peng MW & 19 & 41 & 3 & 3 & 0 & 1,0 \\
\hline Portes A & 50 & 49 & 3 & 1 & 2 & 1,5 \\
\hline Stuart T & 22 & 23 & 3 & 3 & 0 & 1,5 \\
\hline Woo CY & 11 & 11 & 3 & 3 & 0 & 1,5 \\
\hline
\end{tabular}

In a similar way, the HF index was produced for cited authors by applying the above formula, although in this case, the frequency in each database represents the number of times an author appears in the references listed by $\mathrm{H}$-Classics authors. Once again, the first 10 authors are highlighted in colour (see Table 4). The first eight authors coincide with the ranking obtained if only total appearances in the two databases are taken into account, while the ninth and tenth authors have changed. Aldrich appears as the leading author in this field, followed by Miller and Shumpeter, who were cited the same number of times. According to this study and the data at the time it was done, these three researchers can be considered the most influential authors in entrepreneurship studies. 
Table 4. FH for main cited by H-Classics authors

\begin{tabular}{|c|c|c|c|c|c|c|}
\hline Cited by H-CLASSICS & $\begin{array}{c}\text { H Index } \\
\text { wOS }\end{array}$ & $\begin{array}{l}\text { H Index } \\
\text { SCOPUS }\end{array}$ & Appearances & $\begin{array}{l}\text { Frec } \\
\text { WOS }\end{array}$ & $\begin{array}{l}\text { Frec } \\
\text { Wos }\end{array}$ & FH \\
\hline Aldrich H. E. & 29 & 22 & 147 & 127 & 20 & 80,8 \\
\hline Zahra S.A. & 48 & 48 & 133 & 89 & 44 & 66,5 \\
\hline Miller D. & 50 & 37 & 122 & 101 & 21 & 67,0 \\
\hline Schumpeter J. A. & 2 & 1 & 112 & 89 & 23 & 67,0 \\
\hline Shane S. A. & 21 & 44 & 108 & 79 & 29 & 45,2 \\
\hline Covin J.G. & 30 & 26 & 90 & 67 & 23 & 46,6 \\
\hline Kirzner I. M. & 5 & 7 & 90 & 69 & 21 & 41,0 \\
\hline Barney J.B. & 35 & 26 & 83 & 74 & 9 & 46,3 \\
\hline Porter M.E. & 6 & 34 & 81 & 63 & 18 & 24,8 \\
\hline Cooper A.C. & 21 & 18 & 78 & 57 & 21 & 40,4 \\
\hline Reynolds P. D. & 19 & 20 & 77 & 43 & 34 & 38,4 \\
\hline Gartner W.B. & 24 & 23 & 76 & 43 & 33 & 38,1 \\
\hline Hitt M. A. & 60 & 54 & 68 & 63 & 5 & 35,5 \\
\hline Teece D. J. & 39 & 33 & 67 & 56 & 11 & 35,4 \\
\hline March J.G. & 45 & 17 & 66 & 57 & 9 & 43,8 \\
\hline Eisenhardt K.M. & 42 & 30 & 63 & 53 & 10 & 35,1 \\
\hline Audretsch D.B. & 43 & 52 & 60 & 15 & 45 & 31,4 \\
\hline Dimaggio P. J. & 11 & 17 & 60 & 44 & 16 & 27,0 \\
\hline Williamson O. E. & 35 & 20 & 60 & 46 & 14 & 34,4 \\
\hline Burt R. S. & 33 & 25 & 55 & 48 & 7 & 30,3 \\
\hline Hannan M. T. & 68 & 29 & 55 & 36 & 19 & 30,9 \\
\hline Burgelman R. A. & 16 & 11 & 52 & 39 & 13 & 28,4 \\
\hline Granovetter M. S. & 2 & 8 & 52 & 36 & 16 & 20,0 \\
\hline McDougall P. P. & 24 & 23 & 51 & 39 & 12 & 25,8 \\
\hline Nelson R. R. & 24 & 37 & 51 & 35 & 16 & 23,5 \\
\hline Weick K.E. & 36 & 25 & 51 & 43 & 8 & 28,7 \\
\hline Evans D. S. & 43 & 12 & 50 & 36 & 14 & 31,2 \\
\hline MacMillan I. C. & 33 & 31 & 50 & 33 & 17 & 25,3 \\
\hline Mintzberg $\mathrm{H}$. & 35 & 20 & 49 & 33 & 16 & 26,7 \\
\hline
\end{tabular}

Source: Authors.

\subsection{Journals}

Another aspect to take into account is the journals in which the texts related to entrepreneurship are published. Based on the 78 possible titles, 196 WoS and 85 Scopus texts of the H-Classics were first consolidated into one list showing only those journals that have a frequency equal to or above two times, which includes $84 \%$ of the total journals. An HF index could then be developed by means of the following formula:

$$
H F=\frac{\text { WoS Frequency } * \text { WOS F.Imp. }+ \text { Scopus Frequency } * \text { Scopus F.Imp } .}{\text { WoS F.Imp }+ \text { Scopus F.Imp } .}
$$

Table 5 displays the results. The leading journals in which the classics of entrepreneurship have been published are those shaded in grey, with the Journal of Business Venturing in first place, followed by the Strategic Management Journal and Academy of Management Journal.

Table 5. FH for main journals (H-Classics authors)

\begin{tabular}{|l|c|c|c|c|c|c|}
\hline \multicolumn{1}{|c|}{ Title } & Frec & Frec & Frec & FI WOS & SJR \\
\hline & Scopus & Tot & $\mathbf{2 0 1 4}$ & $\mathbf{2 0 1 4}$ & FH \\
\hline Journal of business venturing & 23 & 24 & 47 & 3.678 & 5,561 & 23,60 \\
\hline Strategic management journal & 23 & 1 & 24 & 3.341 & 6,392 & 8,55 \\
\hline Academy of management journal & 15 & 1 & 16 & 6.448 & 9,398 & 6,70 \\
\hline Academy of management review & 11 & 0 & 11 & 7.475 & 11,91 & 4,24 \\
\hline Research policy & 9 & 2 & 11 & 3.117 & 2,317 & 6,02 \\
\hline Journal of management & 8 & 2 & 10 & 6.071 & 7,232 & 4,74 \\
\hline Administrative science quarterly & 9 & 0 & 9 & 3.333 & 6,23 & 3,14 \\
\hline Entrepreneurship theory and practice & 3 & 6 & 9 & 3.144 & 2,811 & 4,42 \\
\hline Small business economics & 4 & 5 & 9 & 1.795 & 1,459 & 4,45 \\
\hline Journal of international business studies & 6 & 2 & 8 & 3.563 & 3,236 & 4,10 \\
\hline Journal of marketing & 8 & 0 & 8 & 3.938 & 7,332 & 2,80 \\
\hline Management science & 6 & 2 & 8 & 2.482 & 3,393 & 3,69 \\
\hline Journal of political economy & 7 & 0 & 7 & 3.593 & 13,477 & 1,47 \\
\hline
\end{tabular}




\begin{tabular}{|l|c|c|c|c|c|c|}
\hline \multicolumn{1}{|c|}{ Title } & Frec & Frec & Frec & FI WOS & SJR & FH \\
\hline American economic review & Scopus & Tot & $\mathbf{2 0 1 4}$ & $\mathbf{2 0 1 4}$ & ( \\
\hline American sociological review & 3 & 2 & 5 & 3.673 & 9,543 & 1,39 \\
\hline Harvard business review & 3 & 2 & 5 & 4.390 & 3,916 & 2,53 \\
\hline American journal of sociology & 3 & 1 & 4 & 3.574 & 0,577 & 2,73 \\
\hline Journal of applied psychology & 2 & 2 & 4 & 4.799 & 3,341 & 2,03 \\
\hline Organization science & 2 & 2 & 4 & 3.775 & 8,098 & 2,00 \\
\hline Annual review of sociology & 3 & 0 & 3 & 4.080 & 2,843 & 1,77 \\
\hline Entrepreneurship and regional development & 0 & 3 & 3 & 1.519 & 1,29 & 1,38 \\
\hline Journal of finance & 2 & 1 & 3 & 5.424 & 17,138 & 1,24 \\
\hline Journal of financial economics & 3 & 0 & 3 & 4.047 & 10,116 & 0,86 \\
\hline Review of economic studies & 3 & 0 & 3 & 4.038 & 11,066 & 0,80 \\
\hline Academy of management annals & 2 & 0 & 2 & 7.769 & 1,139 & 1,74 \\
\hline Industrial and corporate change & 1 & 1 & 2 & 1.260 & 1,139 & 1,00 \\
\hline Journal of business research & 1 & 1 & 2 & 1.480 & 1,183 & 1,00 \\
\hline Journal of labor economics & 2 & 0 & 2 & 1.893 & 5,3 & 0,53 \\
\hline Journal of product innovation management & 1 & 1 & 2 & 1.696 & 1,975 & 1,00 \\
\hline Journal of world business & 1 & 1 & 2 & 2.388 & 1,709 & 1,00 \\
\hline Organization studies & 0 & 2 & 2 & 2.886 & 2,836 & 0,99 \\
\hline Quarterly journal of economics & 2 & 0 & 2 & 6.654 & 22,541 & 0,46 \\
\hline Research in organizational behavior & 1 & 1 & 2 & 1.562 & 1,637 & 1,00 \\
\hline Yale law journal & 2 & 0 & 2 & 4.032 & 1,922 & 1,35 \\
\hline & & & & \\
\hline
\end{tabular}

Source: Authors.

Regarding journals in which the work of authors most seminal to entrepreneurship studies appears, that is, those cited by $\mathrm{H}$ Classics, the results are quite similar. Of all the journals analysed 4,489 from WoS and 2,588 from Scopus - after errors and duplications were eliminated, different titles standardised and both lists unified into a single file, 4,953 journals remained with a total frequency of 20,151 . Of these, because of limited space, a list was developed of texts appearing over 60 times (i.e. 35\% of the total), and, after the aforementioned formulas and mechanisms were applied, a similar ranking was produced (see Table 6).

Table 6. FH for main journals (authors cited by H-Classics)

\begin{tabular}{|c|c|c|c|c|c|c|}
\hline Title & $\begin{array}{l}\text { Frec } \\
\text { Wos }\end{array}$ & $\begin{array}{c}\text { Frec } \\
\text { SCOPUS }\end{array}$ & $\begin{array}{l}\text { Frec. } \\
\text { Tot. }\end{array}$ & $\begin{array}{c}\text { FI WOS } \\
2014\end{array}$ & $\begin{array}{l}\text { SJR } \\
2014\end{array}$ & FH \\
\hline STRATEGIC MANAGEMENT JOURNAL & 677 & 123 & 800 & 3,341 & 6,392 & 313,2 \\
\hline JOURNAL OF BUSINESS VENTURING & 387 & 383 & 770 & 3,678 & 5,561 & 384,6 \\
\hline ACADEMY OF MANAGEMENT REVIEW & 426 & 132 & 558 & 7,475 & 11,91 & 245,4 \\
\hline ACADEMY OF MANAGEMENT JOURNAL & 440 & 111 & 551 & 6,448 & 9,398 & 244,9 \\
\hline ADMINISTRATIVE SCIENCE QUARTERLY & 455 & 61 & 516 & 3,333 & 6,23 & 198,3 \\
\hline ENTREPRENEURSHIP THEORY AND PRACTICE & 189 & 158 & 347 & 3,144 & 2,811 & 174,4 \\
\hline AMERICAN JOURNAL OF SOCIOLOGY & 228 & 51 & 279 & 3,545 & 3,341 & 142,1 \\
\hline ORGANIZATION SCIENCE & 216 & 28 & 244 & 3,775 & 8,098 & 87,8 \\
\hline MANAGEMENT SCIENCE & 175 & 36 & 211 & 2,482 & 3,393 & 94,7 \\
\hline JOURNAL OF MANAGEMENT & 157 & 50 & 207 & 6,071 & 7,232 & 98,8 \\
\hline AMERICAN ECONOMIC REVIEW & 149 & 46 & 195 & 3,673 & 9,543 & 74,6 \\
\hline AMERICAN SOCIOLOGICAL REVIEW & 156 & 35 & 191 & 4,390 & 3,916 & 99,0 \\
\hline HARVARD BUSINESS REVIEW & 151 & 35 & 186 & 1,574 & 0,577 & 119,9 \\
\hline JOURNAL OF INTERNATIONAL BUSINESS STUDIES & 144 & 42 & 186 & 3,563 & 3,236 & 95,5 \\
\hline JOURNAL OF SMALL BUSINESS MANAGEMENT & 36 & 140 & 176 & 1,353 & 1,124 & 83,2 \\
\hline JOURNAL OF POLITICAL ECONOMY & 117 & 45 & 162 & 3,593 & 13,477 & 60,2 \\
\hline JOURNAL OF MARKETING & 161 & 0 & 161 & 3,938 & 7,332 & 56,3 \\
\hline RESEARCH POLICY & 126 & 34 & 160 & 3,117 & 2,317 & 86,8 \\
\hline SMALL BUSINESS ECONOMICS & 36 & 112 & 148 & 1,795 & 1,459 & 70,1 \\
\hline FRONTIERS ENTREPRENEURSHIP RESEARCH & 78 & 65 & 143 & - & - & - \\
\hline QUARTERLY JOURNAL OF ECONOMICS & 66 & 32 & 98 & 6,654 & 22,541 & 39,7 \\
\hline JOURNAL OF MANAGEMENT STUDIES & 66 & 26 & 92 & 3,763 & 4,047 & 45,3 \\
\hline ORGANIZATION STUDIES & 70 & 19 & 89 & 2,886 & 2,836 & 44,7 \\
\hline JOURNAL OF APPLIED PSYCHOLOGY & 55 & 31 & 86 & 4,799 & 6,173 & 41,5 \\
\hline CALIFORNIA MANAGEMENT REVIEW & 62 & 21 & 83 & 1,250 & 1,616 & 38,9 \\
\hline ECONOMETRICA & 62 & 16 & 78 & 3,889 & 16,297 & 24,9 \\
\hline JOURNAL OF FINANCE & 57 & 14 & 71 & 5,424 & 17,138 & 24,3 \\
\hline JOURNAL OF MARKETING RESEARCH & 68 & 0 & 68 & 2,256 & 4,488 & 22,7 \\
\hline JOURNAL OF ECONOMIC LITERATURE & 44 & 20 & 64 & 5,354 & 11,259 & 27,7 \\
\hline
\end{tabular}

Source: Authors. 
As can be seen in the above table, the two leading journals in both rankings are the same - Journal of Business Venturing and Strategic Management Journal - with basically the same periodicals appearing in both rankings. In the second list (i.e. journals that published seminal entrepreneurship studies), new lines of research appeared in periodicals such as Frontiers of Entrepreneurship Research, Journal of Management Studies, California Management Review, Econometrica, Journal of Marketing Research and Journal of Economic Literature, among other more prominent journals.

This type of classification has a strongly dynamic character, which is why the journals were assessed based on the latest available impact factors (i.e. for 2014). This method is mainly useful as a way to assess, for each period, which publications have been - and many continue to be - the most representative of this field. This result holds true independent of the order in which these journals are ranked at any particular time, the way the ranking is being used or even the way the ranking is calculated.

This type of ranking has been described and used in different studies, from Shane (1997) to more recent research such as Sassmannshausen (2012) and Stewart and Cotton (2013). The conclusions reached are similar: it is difficult to develop a definitive classification system because incongruencies can be found in many approaches. Nonetheless, in the majority of lists produced, a consistent core of journals is maintained, similar to the one described above, which contributes to clarifying the nature of a deeply fragmented field of research such as entrepreneurship.

Regarding the themes or subject areas covered by journals that appear in H-Classics, in WoS (196) and Scopus (85), these need to be dealt with cautiously because the classification systems in these databases are different. However, a few themes clearly dominate, namely, business, management, economics, sociology and psychology.

\subsection{Types of texts}

One of the characteristics that differentiates the present study from previous reviews is that it includes texts from a database not taken into account by the most complete previous studies, as mentioned previously (i.e. 85 papers in Scopus). In addition, the present study incorporated types of texts that seldom have been considered (see Table 7). The 281 classics selected include editorials, notes, reviews, books, conference papers and unclassified texts, which make up nearly $27 \%$ of the texts.

Table 7. Type of document Wos and Scopus in the analysis

\begin{tabular}{|c|c|}
\hline Type of documents WOS & Number \\
\hline Article & 147 \\
\hline Article; Proceedings Paper & 15 \\
\hline Editorial Material & 2 \\
\hline Note & 2 \\
\hline Review & 30 \\
\hline Total & 196 \\
\hline Type of documents Scopus & Number \\
\hline Article & 59 \\
\hline Book & 5 \\
\hline Conference Paper & 1 \\
\hline Editorial & 1 \\
\hline Review & 12 \\
\hline (en blanco) & 7 \\
\hline Total & $\mathbf{8 5}$ \\
\hline
\end{tabular}

Source: Authors.

\subsection{Countries and language of publication}

One hundred percent of the texts that were included in this study were published in English, even though the backgrounds of $\mathrm{H}$-Classics authors are diverse. There is a clear preponderance of Anglo-Saxon researchers, especially Americans (292), British (25) and Canadians (22). The origins of sources' first, second and third authors were usually included in the data, but some of these were unknown.

\subsection{Institutional affiliation of $\mathrm{H}$-Classics}

Of all the texts analysed in the Scopus database, 14 did not contain information about H-Classics' institutional affiliation. The same happened with 27 from WoS, as this information is compiled and entered manually. However, the present study compiled this information, when available, thereby dealing with this issue, since the first phase of standardisation allowed the addition of reasonable approximations of the information to be analysed.

Overall, it was possible to extract the affiliations of 349 authors including the second and third authors, where appropriate - of those sources that showed universities, with a frequency equal to or greater than five times. As expected, since the majority of authors are North American, U.S. universities and institutions topped the list in terms of number of mentions, namely, the Universities of Illinois, Maryland and Pennsylvania, as well as Babson College.

It should be noted that no ranking was created because this was not the purpose of the analysis done. As Landström, Harirchi \& Åström (2012) indicate, over time, changes occurred in the most influential universities within entrepreneurship studies. An interesting aspect is the evolution within specific periods in terms of citation frequency, as well as the patterns of collaboration between authors (i.e. when the first and second authors have different affiliations) or the way certain European universities begin to appear more often in terms of citation frequency. The latter include Jonkoping University (Sweden), Stockholm School of Economics (Sweden), Erasmus University Rotterdam (The Netherlands) and University of Giessen (Germany), to cite just a few that appear with greater frequency in the sample, as shown in Table 8 below. 
Table 8. Affiliation of $\mathrm{H}$-Classics

\begin{tabular}{|l|l|}
\hline \multicolumn{1}{|c|}{ Affiliations } & Appearances \\
\hline University Illinois & 15 \\
\hline University Maryland & 10 \\
\hline University Pennsylvania & 10 \\
\hline Babson College & 9 \\
\hline Indiana University & 8 \\
\hline Jonkoping University & 8 \\
\hline Princeton University & 8 \\
\hline University North Carolina & 8 \\
\hline Georgia State University & 7 \\
\hline Stanford University & 7 \\
\hline University Toronto & 7 \\
\hline Arizona State University & 6 \\
\hline Cornell University & 6 \\
\hline Northwestern University & 6 \\
\hline Stockholm School Economics & 6 \\
\hline University Minnesota & 6 \\
\hline Erasmus University Rotterdam & 5 \\
\hline Georgia Institute of Technology & 5 \\
\hline Harvard University Cambridge & 5 \\
\hline Michigan State University & 5 \\
\hline Ohio State University & 5 \\
\hline Rutgers University & 5 \\
\hline UCLA Anderson Graduate School of Management & 5 \\
\hline University Auckland & 5 \\
\hline University Central Florida & 5 \\
\hline University Giessen & 5 \\
\hline
\end{tabular}

Source: Authors

\subsection{Author and H-Classics index keywords}

The sample of keywords was divided into two groups: most cited author keywords and most cited index keywords. Neither group had complete information for all the texts. The first group included 59 texts from Scopus and 136 from WoS without author keywords.
The second group had 34 texts from WoS and 66 from Scopus without index keywords. The results are shown in Table 9. Out of all of the words (i.e. 397 most cited author keywords and 1,422 most cited index keywords), the following stand out as the most frequently used: entrepreneurship, innovation, firm and performance.

Table 9. Most citing author and index keywords

\begin{tabular}{|c|c|c|c|}
\hline Most citing Author Keywords & Appearances & Most Citing Index Keywords & Appearances \\
\hline Entrepreneurship & 28 & firm & 42 \\
\hline Innovation & 7 & performance & 42 \\
\hline Entrepreneurs & 6 & innovation & 31 \\
\hline Social capital & 6 & entrepreneurship & 28 \\
\hline Networks & 5 & industry & 26 \\
\hline Economic development & 4 & strategy & 22 \\
\hline International entrepreneurship & 4 & environment & 22 \\
\hline Technology transfer & 4 & organizations & 20 \\
\hline Biotechnology & 3 & competitive advantage & 20 \\
\hline Born global firms & 3 & management & 19 \\
\hline Business model & 3 & united states & 17 \\
\hline Development blocks & 3 & knowledge & 17 \\
\hline Economic growth & 3 & perspective & 15 \\
\hline International new venture & 3 & market & 15 \\
\hline Internationalization & 3 & evolution & 13 \\
\hline Nascent entrepreneurship & 3 & business & 12 \\
\hline Resource-based view & 3 & growth & 10 \\
\hline Resources & 3 & & 10 \\
\hline Social Network & 3 & & \\
\hline Strategic alliances & 3 & & \\
\hline Strategy & 3 & & \\
\hline Technology & 3 & & \\
\hline
\end{tabular}




\section{Conclusions}

This study combined the techniques of SLR and bibliometric analysis of research output in order to make an updated assessment of the intellectual structure of entrepreneurship. This could contribute to enhancing future research on entrepreneurship theories.

The bibliometric analysis carried out proved that the studies with the highest citation rates in this field were published between 1995 and 2006. These texts, in turn, refer to other work that is considered seminal to entrepreneurship research, indicating that research done in the 90 s has had the most influence, since more than $50 \%$ of referenced sources used by the most cited studies are from this decade. Therefore, in that period, entrepreneurship emerged as a feasible, independent line of research, separate from other branches.

Regarding the most influential authors, besides the rankings that were produced, the results show a core group that repeatedly appears in all bibliographic/bibliometric studies such as the present one, which indicates these authors are the pioneers of entrepreneurship as a research field. These include H. E. Aldrich, S. A. Zahra, S. A. Shane, D. Miller, J. A. Schumpeter, P. P. McDougall, V. Nee, B. M. Oviatt, H. J. Sapienza and I. Kirzner, who should be recognised as the precursors of this field and not only as the most outstanding researchers of related areas who happen to have written about entrepreneurs.

Concerning the journals that have published and continue to publish outstanding works in this field, obviously the majority belong to areas within business, management and economics. Important journals include the Journal of Business Venturing, Strategic Management Journal and Academy of Management Journal, as well as specialised journals such as Entrepreneurship Theory and Practice and Frontiers of Entrepreneurship Research, which have achieved prominence in the field and whose prestige is still growing.

In addition, it should be noted that entrepreneurship research continues to be strongly marked by an Anglo-Saxon tradition, with a predominant number of American, British and Canadian authors. However, the findings show that, gradually, other institutional affiliations have appeared that are becoming more important, as may be the case with European universities such as Jonkoping University (Sweden), Stockholm School of Economics (Sweden), Erasmus University Rotterdam (The Netherlands) and University of Giessen (Germany).

Many of this study's limitations are inherent in the specific problems present in bibliometric analyses in general. These can include the motivations behind the citations on which analyses are based, since many citations are not always due to the quality of the cited texts but instead to other aspects such as previous familiarity with the cited authors. Others issues in this study can be considered both weaknesses or strengths, since different databases were used that, while they contribute texts not included in other studies thus far, also incorporate citation patterns calculated in distinct ways, which undoubtedly affects the results.

In conclusion, possible future lines of research could complete the present study's analyses with other relational studies based on maps of entrepreneurship studies. These can show, for example, cognitive evolution through an analysis of co-words, research collaboration through an analysis of authors' co-occurrence or different new lines of research by way of authors' co-citations.

The present study confirmed that a literary corpus exists centred on entrepreneurship research that appears not only in this research but also in previous, more comprehensive bibliometric studies. This finding guarantees the viability of creating a specific category for entrepreneurship in the main research baselines. It makes little sense that journal articles such as Baumol (1996), Miller (1983) and Shane and Vekataraman (2000) should be classified under economics, management or operational research when, even though related to these fields, these papers are clear examples of studies specifically about entrepreneurship.

\section{References}

Amit, R., Glosten, L., \& Muller, E. (1993). Challenges to theory development in entrepreneurship research. Journal of Management studies, 30(5), 815834.

Audretsch, D. B., Kuratko, D. F., \& Link, A. N. (2015). Making sense of the elusive paradigm of entrepreneurship. Small Business Economics, 45(4), 703-712.

Baumol, W. J. (1996). Entrepreneurship: productive, unproductive, and destructive. Journal of Business Venturing, 11(1), 3-22.

Beltrán Galvis, O. A. (2005). Revisiones sistemáticas de la literatura. Rev. colomb. gastroenterol, 20(1), 60-69.

Bornmann, L., \& Marx, W. (2011). The $\mathrm{h}$ index as a research performance indicator. Eur Sci Ed, 37(3), 77-80.

Boulard, M. M. (2011). La dirección de empresas ante los retos del siglo XXI: homenaje al profesor Juan José Renau Piqueras. Valencia: Universitat de València.

Bygrave, W. D., \& Hofer, C. W. (1991). Theorizing about entrepreneurship. Entrepreneurship theory and Practice, 16(2), 13-22.

Cuervo, A., Ribeiro, D., \& Roig, S. (2006). Entrepreneurship: conceptos, teoría y perspectiva. Introducción. Entrepreneurship: Conceptos, teoría y perspectiva, 9-25.

Denyer, D., \& Neely, A. (2004). Introduction to special issue: innovation and productivity performance in the UK. International Journal of Management Reviews, 5(3-4), 131-135.

Díaz, C. (2002). La creación de empresas: revisión histórica de teorías y escuelas. Trujillo: Ediciones La Coria. Fundación Xavier de Salas.

Falagas, M. E., Pitsouni, E. I., Malietzis, G. A., \& Pappas, G. (2008). Comparison of PubMed, Scopus, Web of Science, and Google scholar: strengths and weaknesses. The FASEB journal, 22(2), 338-342.

Frank, H., \& Landström, H. (2015). What makes entrepreneurship research interesting? Reflections on strategies to overcome the rigour-relevance gap. Entrepreneurship \& Regional Development, 1-25.

Garfield, E. (1977). Introducing citation classics: the human side of scientific reports. Current Contents, 1, 5-7.

Gartner, W. B. (1985). A conceptual framework for describing the phenomenon of new venture creation. Academy of management review, 10(4), 696-706.

Genescà, E., \& Aponte, M. (2003). Creación de empresas (Vol. 33). Barcelona: Univ. Autònoma de Barcelona.

Gomez-Jauregui, V., Gomez-Jauregui, C., Manchado, C., \& Otero, C. (2014). Information management and improvement of citation indices. International Journal of Information Management, 34(2), 257-271.

Jones, M. V., Coviello, N., \& Tang, Y. K. (2011). International entrepreneurship research (1989-2009): a domain ontology and thematic analysis. Journal of Business Venturing, 26(6), 632-659.

Karatas-Ozkan, M., \& Chell, E. (2013). Handbook of research in small business and entrepreneurship. Cheltemham, UK: Edward Elgar. 
Khalid, K. S., \& Kunz, R. (2003). Systematic reviews to support evidencebased medicine. Berlin: Springer.

Kitchenham, B. (2004). Procedures for performing systematic reviews. Keele, UK: Keele University.

Landström, H., Harirchi, G., \& Åström, F. (2012). Entrepreneurship: exploring the knowledge base. Research Policy, 41(7), 1154-1181.

Libmann, F. (2007). Web of Science, Scopus, and classical online: philosophies of searching. Online, 31(3), 36-40.

Liñán, F., \& Fayolle, A. (2015). A systematic literature review on entrepreneurial intentions: citation, thematic analyses, and research agenda. International Entrepreneurship and Management Journal, 11(4), 907-933.

Low, M. B. (2001). The adolescence of entrepreneurship research: specification of purpose. Entrepreneurship: Theory and practice, 25(4), 1726.

Low, M. B., \& MacMillan, I. C. (1988). Entrepreneurship: past research and future challenges. Journal of management, 14(2), 139-161.

Manchado del Val, C. (2015). Análisis de criterios de visibilidad e Impacto Visual: metodología de uso en proyectos de infraestructuras. Doctoral Dissertation, University of Cantabria.

Marin-Garcia, J. A. (2008). Guía de investigación para el desarrollo de la carrera del profesorado: organización de empresas. Valencia: Editorial de la Universidad Politécnica de Valencia.

Martínez Sánchez, M. Á. (2014). Aplicación de técnicas bibliométricas en el análisis del área de trabajo social. Granada: Universidad de Granada.

Meho, L. I., \& Yang, K. (2007). Impact of data sources on citation counts and rankings of LIS faculty: Web of Science versus Scopus and Google Scholar.Journal of the american society for information science and technology, 58(13), 2105-2125.

Miller, D. (1983). The correlates of entrepreneurship in three types of firms. Management Science, 29(7), 770-791.

Minniti, M. (2013). The Dynamics of Entrepreneurship: Evidence from Global Entrepreneurship Monitor Data. Oxford: Oxford University Press.

Moroz, P. W., \& Hindle, K. (2012). Entrepreneurship as a process: Toward harmonizing multiple perspectives. Entrepreneurship Theory and Practice,36(4), 781-818.

Norris, M., \& Oppenheim, C. (2007). Comparing alternatives to the Web of Science for coverage of the social sciences' literature. Journal of Informetrics,1(2), 161-169.

Petticrew, M., \& Roberts, H. (2006). Systematic reviews in the social sciences: a practical guide. Malden, MA: Blackwell Publishing.

Pittaway, L., Holt, R., \& Broad, J. (2014). 6. Synthesising knowledge in entrepreneurship research-the role of systematic literature. Handbook of Research on Small Business and Entrepreneurship. Cheltenham: Edward Elgar Publishing.

Pittaway, L., Robertson, M., Munir, K., Denyer, D., \& Neely, A. (2004). Networking and innovation: a systematic review of the evidence. International Journal of Management Reviews, 5(3-4), 137-168.

Sassmannshausen, S. P. (2012). 99 entrepreneurship journals: $A$ comparative empirical investigation of rankings, impact, and $\mathrm{H} / \mathrm{HC}$ index (No. 2012-002). Schumpeter Discussion Papers.

Schmidt, F. L., \& Hunter, J. E. (2014). Methods of meta-analysis: Correcting error and bias in research findings. Thousand Oaks, CA: Sage publications.

Schreiber, M. (2010). Twenty Hirsch index variants and other indicators giving more or less preference to highly cited papers. Annalen der Physik, 522(8), 536-554.

Shane, S. A. (1997). Who is publishing the entrepreneurship research? Journal of Management, 23(1), 83-95.

Shane, S., \& Venkataraman, S. (2000). The promise of entrepreneurship as a field of research. Academy of management review, 25(1), 217-226.
Stevenson, H. H., \& Jarillo, J. C. (2007). A Paradigm of Entrepreneurship: Entrepreneurial Management. Berlin: Springer.

Stewart, A., \& Cotton, J. (2013). Making sense of entrepreneurship journals: Journal rankings and policy choices. International Journal of Entrepreneurial Behavior \& Research, 19(3), 303-323.

Teixeira, A. A., \& Ferreira, E. (2013). Intellectual structure of the entrepreneurship field: a tale based on three core journals. Journal of Innovation Management, 1(2), 21-66.

Thorpe, R., Holt, R., Macpherson, A., \& Pittaway, L. (2005). Using knowledge within small and medium-sized firms: a systematic review of the evidence. International Journal of Management Reviews, 7(4), 257281.

Tranfield, D., Denyer, D., \& Smart, P. (2003). Towards a methodology for developing evidence-informed management knowledge by means of systematic review. British journal of management, 14(3), 207-222.

Veciana, J. M. (2007). Entrepreneurship as a Scientific Research Programme. Berlin: Springer.

Vesper, K. H. (1983). Entrepreneurship and national policy (Vol. 3). Chicago: Walter E. Heller International Corporation Institute for Small Business.

Vieira, E., \& Gomes, J. (2009). A comparison of Scopus and Web of Science for a typical university. Scientometrics, 81(2), 587-600.

Wang, X., \& Jessup, L. M. (2014). A review and synthesis of entrepreneurship research: towards an integrative model of dependent variables. Journal of Entrepreneurship, 23(2), 163-199.

Received: 17 June 2016

Revisions required: 02 January 2017

Accepted: 04 March 2017 